\title{
ODOS MIKROBIOMAS: IVAIROVE் IR REIKŠMĖ ODOS SVEIKATAI
}

\author{
Rita Jankauskienė, Gražina Šniepienė \\ Klaipédos valstybine kolegija, Klaipédos universitetas
}

Raktažodžiai: odos mikrobiomas, ịvairovè, sąveikos, odos sveikata.

\begin{abstract}
Santrauka
Odos ir aplinkos sąveika yra sudètinga ekosistema, kolonizuota daugelio mikroorganizmų, kurie koegzistuoja išlaikydami pusiausvyrą. Viename kvadratiniame žmogaus odos centimetre yra iki milijardo mikroorganizmų. Ivairių sistematinių grupių atstovai - bakterijos, grybeliai, erkutès ir virusai formuoja odos mikrobiomą. Sveikos odos mikrobiomas slopina patogeninių mikroorganizmų, tokių kaip Staphylococcus aureus, Cutibacterium acnes ir kitų, kolonizaciją ir yra pagrindinis epidermio barjero veikimo komponentas. Taip komensaliniai odos mikrobiomo organizmai prisideda prie sveikos odos palaikymo, atitolina ligos vystymąsi ar palengvina jos eigą. Šioje apžvalgoje nagrinejjama žmogaus odos mikrobiomo organizmų įvairovès bei funkcijų sąveika su šeimininko endogeniniais ir egzogeniniais veiksniais.
\end{abstract}

\section{Ivadas}

Oda yra didžiausias ir vienas iš intensyviausiai veikiančių kūno organų, apimantis maždaug $1,8 \mathrm{~m}^{2}$ paviršiaus plotą [1-2]. Ji atlieka gyvybiškai svarbią barjerinę funkciją tarp kūno vidinès terpès ir išorinès aplinkos, ribodama vandens praradimą, kenksmingų medžiagų bei patogeninių mikroorganizmų invaziją, tokiu būdu apsaugodama nuo infekcinių ligų vystymosi. Odoje vykstančios imuninės reakcijos užtikrina šeimininko apsaugą ir audinių homeostazę. Odą kolonizuojantys mikroorganizmai nuolat sąveikauja su epidermio ląstelèmis ir daro poveikị šeimininko imunitetui. Imuninès pusiausvyros palaikymas užtikrina šeimininko odos ir viso organizmo sveikatą [3].

Žmogaus epitelio paviršių kolonizuoja apie 100000 milijardų mikroorganizmų, kurių apytikrè bendroji mase -2 kilogramai. Apie 95 proc. visų bakterijų randama virškinimo sistemoje - nuo 1000 iki 10000 taksonominių vienetų [4]. Mikroorganizmų mes turime daugiau, nei savų ląstelių - vienai žmogaus ląstelei tenka 1,3 mikroorganizmo. Nors daugèja įrodymų, kad mūsų kūne ir ant jo gyvenantys mikroorganizmai yra svarbūs žmonių sveikatai ir ligoms, daugelis jų funkcijų ir padarinių vis dar nėra gerai suprantami [5]. Odos bakterijų bendrijos ịvairiose kūno vietose varijuoja kokybiškai ir kiekybiškai. Šiuos skirtumus lemia ịvairių kūno vietų, kaip mikroorganizmų gyvenamosios aplinkos, sąlygų (pH, temperatūra, maisto medžiagos, antimikrobinès molekulès, deguonies koncentracija ir kt.) kaita $[1 ; 4 ; 6]$. Be to, odos struktūros, tokios kaip plaukų folikulai, riebalinès, ekrininès ir apokrininès prakaito liaukos, sudaro atskiras nišas, kuriose yra unikali mikrobiota [6]. Nors odos epitelio aplinka turètuc būti nepalanki mikroorganizmų augimui dèl temperatūros nepastovumo, rūgščios $\mathrm{pH}$ reakcijos bei greito epidermio atsinaujinimo, nustatyta maždaug milijardas bakterijų, gyvenančių viename kvadratiniame odos centimetre [7]. Su oda asocijuoti mikroorganizmai, t.y. bakterijos, grybeliai, erkutès ir virusai formuoja odos mikrobiomą, specifines ekologines nišas, padeda išvengti ligų, ar atvirkščiai, jas sukelia [8]. Pavyzdžiui, kai kurios bakterijos riboja kitų augimą, hidrolizuodamos sebumo lipidus ị toksiškas riebiąsias rūgštis, tačiau Staphylococcus aureus sukeltos oportunistinès odos infekcijos dažnėja ir tampa vis sunkiau valdomos. Neinfekcinès odos ligos, tokios kaip atopinis dermatitas, psoriazè, rožè ir aknè (Acne vulgaris arba paprastieji spuogai) siejamos su odos mikroorganizmų bendrijų pokyčiais [1]. Pasikeitusi bakterijų bendrijos struktūra kartu su epitelio disfunkcija, imuninès sistemos sutrikimais ar per dideliu patogeninių mikroorganizmų skaičiumi yra pagrindinè odos patologijų priežastis [9] (1 pav.).

Šiuolaikiniai odos mikrobiomo tyrimai, orientuoti i taksonominę įvairovę, padeda paaiškinti mikroorganizmų pasiskirstymo odos paviršiuje [10] ar ligų atsiradimo [11] mechanizmus. Žmogaus odos mikrobiomo sąveikos su šeimininku ir kitais mikroorganizmais analizè atskleidžia naujas ligų terapijos, gydymo strategijų bei prevencinių priemonių taikymo galimybes [6].

Darbo tikslas - remiantis naujausiais moksliniais pasiekimais, apžvelgti sveikos odos epitelio mikrobiomo įvairovę, atsižvelgiant $i$ ịvairius veiksnius, ịskaitant anatomines odos vietas, lytinę brandą ir odos fiziologiją. Aptarti moksliniai 
rezultatai gali būti panaudoti kuriant naujas terapines ir prevencines strategijas.

\section{Tyrimo objektas ir metodai}

Tyrimo objektas - nagrinejama tema mokslinèse duomenų bazèse paskelbtos publikacijos. Paieška buvo atliekama 2019 m. gegužès-rugsèjo mėnesiais 4 mokslinèse duomenų bazėse: ScienceDirect, Pubmed, EBSCO (Health Source-Consumer Edition; Health Source: Nursing/Academic Edition; Medline) ir SpringerLink. Paieškai buvo naudojami raktinių žodžių junginiai, atitinkantys tyrimo tikslą: ,žmogaus odos mikrobiomas“, „odos bakterijų bendrijos", „odos bakterijų ịvairovė“. Atlikus pradinę paiešką, iš viso buvo rastos 841 publikacijos: ScienceDirect duomenų bazeje - 502 (per 10 metų laikotarpi 493 (98,21\%); per 5 metus - 397 (79,08\%)); PubMed - 102 (96 (94,12\%) ir $62(60,78 \%)$ atitinkamai); EBSCO - $23(23(100 \%)$ ir 16 $(69,57 \%)$ atitinkamai); SpringerLink - 214 (214 (100\%) ir $182(85,05 \%)$ atitinkamai). Pritaikius atrankos kriterijus, rasta 314 straipsnių. Atmestos senesnès nei 10 metų, ne viso teksto, ne anglų kalba parašytos, mokamos publikacijos bei dublikatai. Netinkami straipsniai nebuvo ịtraukiami ị literatūros sąrašą. Teksto analizè buvo atliekama tų studijų, kuriose nagrinejjama sveikos odos mikrobiomo ịvairove, funkcijos ir reikšmė odos sveikatai. Taikyti nuoseklūs publikacijų analizès metodai, remiantis sisteminès literatūros apžvalgos ir metaanalizès kontroliniu sąrašu [12].

\section{Rezultatai ir jų aptarimas}

Oda, kaip mikroorganizmų gyvenamoji aplinka, yra labai dinamiška ir įvairi, priklausomai nuo jos storio, reljefo, plauko folikulų bei liaukų tankio. Prakaito liaukos (ekrininès ir apokrininès), riebalinès liaukos ir plauko folikulai suteikia mikroorganizmams unikalią mikroaplinką bei maisto medžiagas. Ekrininès liaukos ị odos paviršių nuolat išskiria prakaitą, kuriame gausu vandens ir natrio chlorido, kiek mažiau - karbamido, šlapimo rūgšties, baltymų, pieno rūgšties ir ịvairių aminorūgščių. Riebalinès liaukos išskiria sebumą, kuris apsaugo ir patepa odą bei suformuoja antibakterinị hidro-lipidinị barjerą. Sebumą sudaro trigliceridai ir riebiosios rūgštys, vaškų esteriai ir skvalenas [13]. Raginiame epitelio sluoksnyje (stratum corneum) daugiausia yra baltymų ir lipidų, nedidelis kiekis vandens ir kitų medžiagų. Odos paviršiaus terpe rūgštine $-\mathrm{pH}$ $(\sim 5)$. Apsaugai nuo patogenų invazijos, gausu antibakterinių molekulių, tokių kaip laisvosios riebalų rūgštys, sfingozinas, azoto oksidas, imunoglobulinai ir antimikrobiniai peptidai [14]. Priklausomai nuo odos topografijos, yra iš dalies uždarų sričių, kur temperatūra ir drègmé didesnè (kirkšnys, kojų tarpupirščiai), nei labai sausų sričių (kojos ir rankos) ir didelio paviršinès temperatūros svyravimo [4]. Riebios kūno sritys (atskiros veido sritys, kūno raukšlès, nugara ir kt.) pasižymi skirtingu deguonies režimu, lyginant su sausomis ir drègnomis sritimis [5]. Mikrobiomo sudeties savitumą lemia ir aplinkos veiksniai, tokie kaip naudojamas muilas, kosmetika, antibiotikų vartojimas, žmogaus veikla, temperatūra, drègmė ir UV spindulių poveikis [15]. Minèti autoriai pažymi, kad odos mikrobiomo įvairovès pokyčiai siejami ir su lètinèmis uždegiminèmis odos ligomis, îskaitant atopinị dermatitą, psoriazę ir spuogus.

Suaugusio žmogaus sveikos odos topografinio tyrimo metu 20 kūno vietų nustatyta, kad odos mikrobiomą formuoja daugiau nei 1000 skirtingų rūšių 19 tipų bakterijų [16-18]. Išskirti 4 dominuojantys bakterijų tipai: Actinobacteria (t.y. Corynebacteriaceae, Propionibacteriaceae) (52\%), Firmicutes (t.y. Staphylococcaceae) (24 \%), Proteobacteria (17\%), ir Bacteroidetes (7 \%) [15-16] (2 pav.). Daugiau nei 60 proc. bakterijų rūšių priklauso trims gentims: Staphylococcus (Firmicutes), Corynebacterium ir Propionibacterium (Actinobacteria) $[11 ; 16]$.

Sveikos odos mikrobiome svarbų vaidmenị atlieka komensalinès bakterijos Staphylococcus epidermidis (toliau - S. epidermidis). Šios bakterijos gerai prisitaiko prie didelio druskingumo sąlygų ir gali prakaite esantị karbamidą panaudoti kaip azoto šaltinị. Be to, S. epidermidis išskiria adhezinus, kurie palengvina prilipimą prie odos [4]. Palaikydamos odos epitelio rūgštinę terpę, pasižymi antimikrobiniu poveikiu ir apsaugo odą nuo patogeninių bakterijų. Nustatyta, $\operatorname{kad} S$. epidermidis gamina antimikrobinius peptidus, tokius

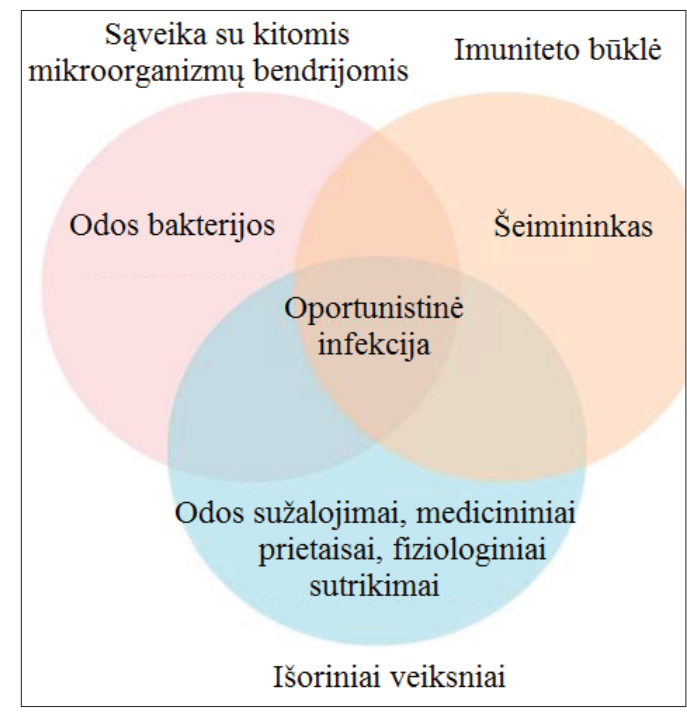

1 pav. Šeimininko, mikrobiomo bakterijų ir išorinės aplinkos sąveika. Modifikuota pagal [34] 
kaip epiderminas, fenolyje tirpius modulino peptidus, Pep5 ir epilancinas $(\mathrm{K} 7,15 \mathrm{X})[15 ; 19]$. Kai kurie tyrimai rodo, $\operatorname{kad} S$. epidermidis gali slopinti C. acnes augimą. Wang ir kt. [2014] teigia, kad S. epidermidis padermès išskiria gintaro rūgštį, kuri pasižymi uždegimo slopinamuoju poveikiu. Christensen ir kt. [2016] nustatè, kad S. epidermidis išskiria polimorfinius toksinus, kurie slopina $C$. acnes augimą. Be to, S. epidermidis išskiria stafilokokinę lipoteichoninę rūgštị, slopinančią uždegimą, padidindama miR-143 ekspresiją ir blokuodama TLR-2 raišką keratinocituose [21].

Virusai, grybeliai ir erkutės taip pat yra svarbios odos mikrobiotos dalys. Nustatyta, kad daugumoje kūno vietu grybeliai sudaro apie 1 proc. mikrobiotos, išskyrus zonas aplink ausis ir kaktą, kur grybelių santykinis gausumas yra didesnis [22]. Pagrinde aptinkami Malassezia genties grybeliai, kurių dažniausi atstovai M. limitta, M. globosa ir M. sympodialis [23]. Malassezia genties atstovai sudaro daugiau nei 90 proc. santykinio grybelių gausumo žmogaus odoje. Veido zonoje dažniausiai vyrauja Malassezia piirata, o sėdmenų, kaklo galinėje dalyje ir kirkšnies raukšlèse - Malassezia globosa. Pèdų zonoje grybelių įvairovè yra didesnè. Čia aptinkamas didelis Aspergillus ir Epicoccum genčiu atstovu santykinis gausumas. Malassezia genties grybeliai priskiriami lipofilams, todèl dažnai susiję su gausiai riebalus išskiriančiomis odos vietomis [24]. Lynn ir kt. (2015) pažymi, kad Malassezia furfur mielès, natūraliai randamos odos paviršiuje, gali prisidèti prie aknès patogenezès.

Gausiai riebalus išskiriančiose odos vietose aptinkamos ir Demodex genties erkutès [25]. Dažniausiai aptinkamos dvi rūšys: Demodex folliculorum ir D. brevis. Nors tai parazitinis patogenas, tačiau aptinkamas ir sveikų žmonių odoje. Remiantis statistika, erkutès nustatomos apie 20-80 proc. suaugusiujų ir 100 proc. vyresnių nei 70 metų vyrų odoje. $D$. folliculorum randamas plaukų folikuluose, o D. brevis odos riebalinėse liaukose ar riebalinėse Meibomo liaukose, atsiveriančiuose vokų pakraščiuose [25].

Genominiai tyrimai leido nustatyti didelę virusų populiaciją odoje: odos viromą. Daugumoje odos vietų didžiają odos viromo dalị sudaro bakteriofagai - DNR virusai, nukreipti prieš Propionibacterium (dabar Cutibacterium) ir Staphylococcus genčių bakterijas. Nepaisant to, kad asmenys neturèjo klinikinių pažeidimų, nustatyti poliomavirusai, papilomos ir raupų virusai [27-28].

Sąlygų įvairovẻ daro odą sudètinga ekosistema, suda-

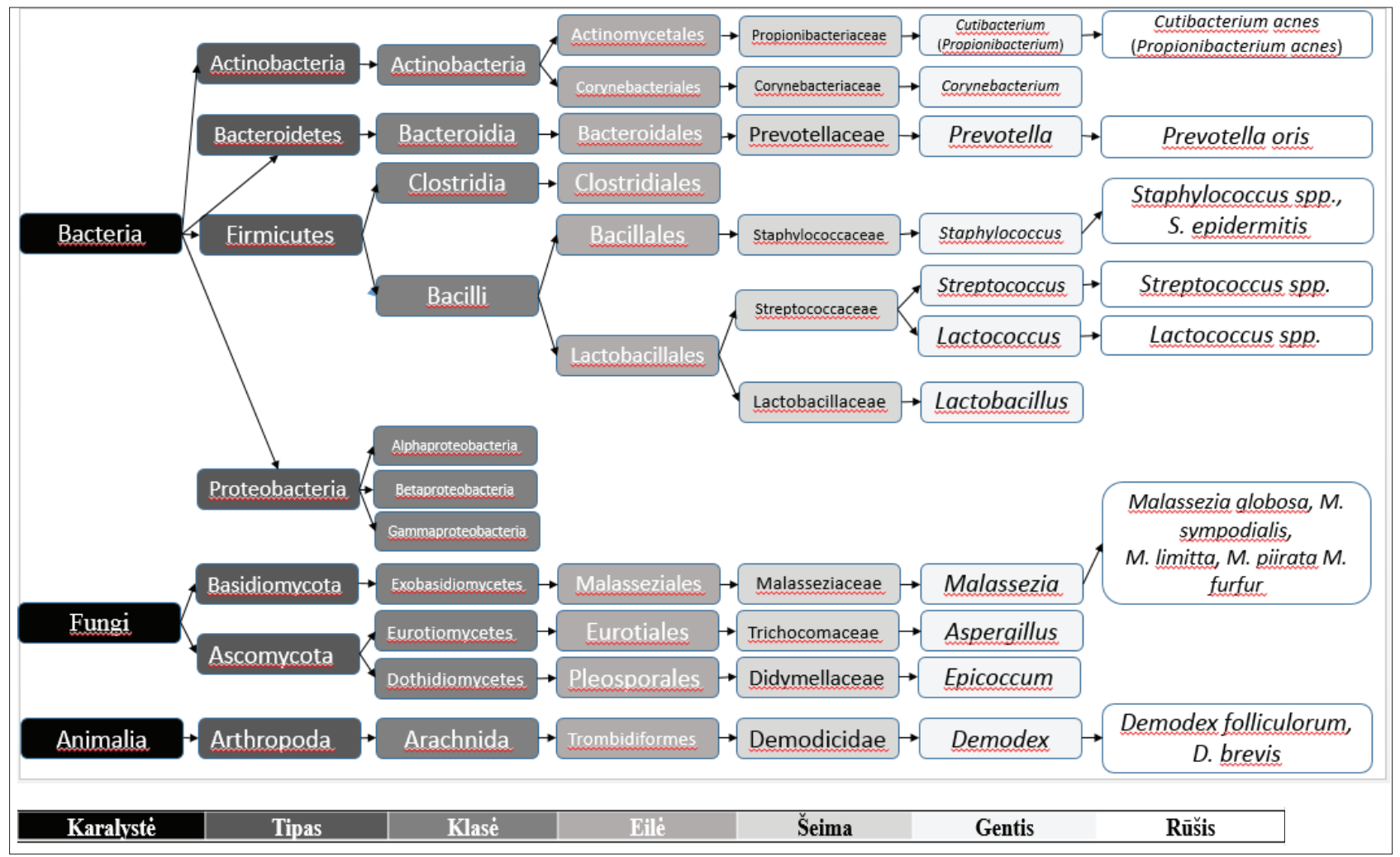

2 pav. Sveikos odos mikroorganizmų klasifikacija. Sudaryta pagal $[1 ; 5 ; 11 ; 15 ; 17-18 ; 24-25 ; 30]$ 
ryta iš daugybès skirtingų buveinių ir mikroorganizmų bendrijų. Bet kurio žmogaus odos mikroorganizmų sudètis yra labai nevienalytė ir priklauso nuo konkrečios odos vietos mikroaplinkos [29]. Žmogaus kūno vietų topografinès ìvairovès tyrimais nustatyta, kad kūno anatominès sritys yra suskirstytos i tris kategorijas: riebias, drègnas ir sausas. Joms būdinga savita mikroorganizmų kompozicija [16]. Nustatyta, kad gausiai sebumą išskiriančiose odos srityse (nelygumuose, raukšlèse, išorinėje ausies landoje, pakaušio, krūtinkaulio, nugaros) bakterijų įvairovè yra mažiausia ir dominuoja Propionibacterium (iskaitant Cutibacterium) ir Staphylococcus genčių bakterijos (3 pav.). Tai parodo, kad nedaugelis bakterijų rūšiu gali išgyventi riebalinio sluoksnio anaerobinèmis sąlygomis.

Drégnose srityse (plaukuotose srityse, alkūnių ir pakinklių linkiuose, kirkšnių ir sėdmenų raukšlèse, paduose, bambos duobutèje ir kt.) vyrauja Corynebacterium genties bakterijos, nors aptinkama ir Staphylococcus genties bakterijų. Sausose vietose, tokiose kaip dilbis, delnai ir sėdmenys, bakterijų ịvairovè yra didžiausia ir aptinkami visų keturių tipų izoliatai $[1 ; 5]$. Mikrobiologiniai žmogaus dilbio tyrimai parodè didelę bakterijų įvairovę, dominuojant Propionibacterium, Corynebacterium, Staphylococcus, Streptococcus ir Acinetobacter [16].

Fiziologiškai panašiose vietose dažnai būna panašios bakterijų bendrijos. Pavyzdžiui, drègni alkūnių ir pakinklių linkiai turi panašias mikroorganizmų kompozicijas, riebalinèse odos vietose dažnai aptinkama Cutibacterium acnes [5]. Mikroorganizmų prisitaikymas prie konkrečių buveinès sąlygų rodo ir tai, kad perkelti iš vienos buveinès ị kitą, pavyzdžiui nuo liežuvio ant kaktos, jų nekolonizuoja arba nekeičia esamos bendrijos struktūros.

Žmogaus egzogeninè aplinka, t.y. ką jis liečia, valgo ir geria, kur maudosi, kuo kvėpuoja, daro poveikị organizmo ekosistemoms, ịskaitant odą. Tai pabrèžia didelę aplinkos sąlygų įtaką mikroorganizmų kolonizacijai kiekviename amžiaus tarpsnyje, ypač ankstyvuoju gyvenimo laikotarpiu, kai formuojasi ịvairios kūno paviršiaus ekosistemos ir imunine sistema [29]. Vaisiaus ir kūdikio odos mikroorganizmų kolonizacijai didelès reikšmès turi motinos gimdymo takų mikrobiota, mityba, psichologinis stresas ir var-

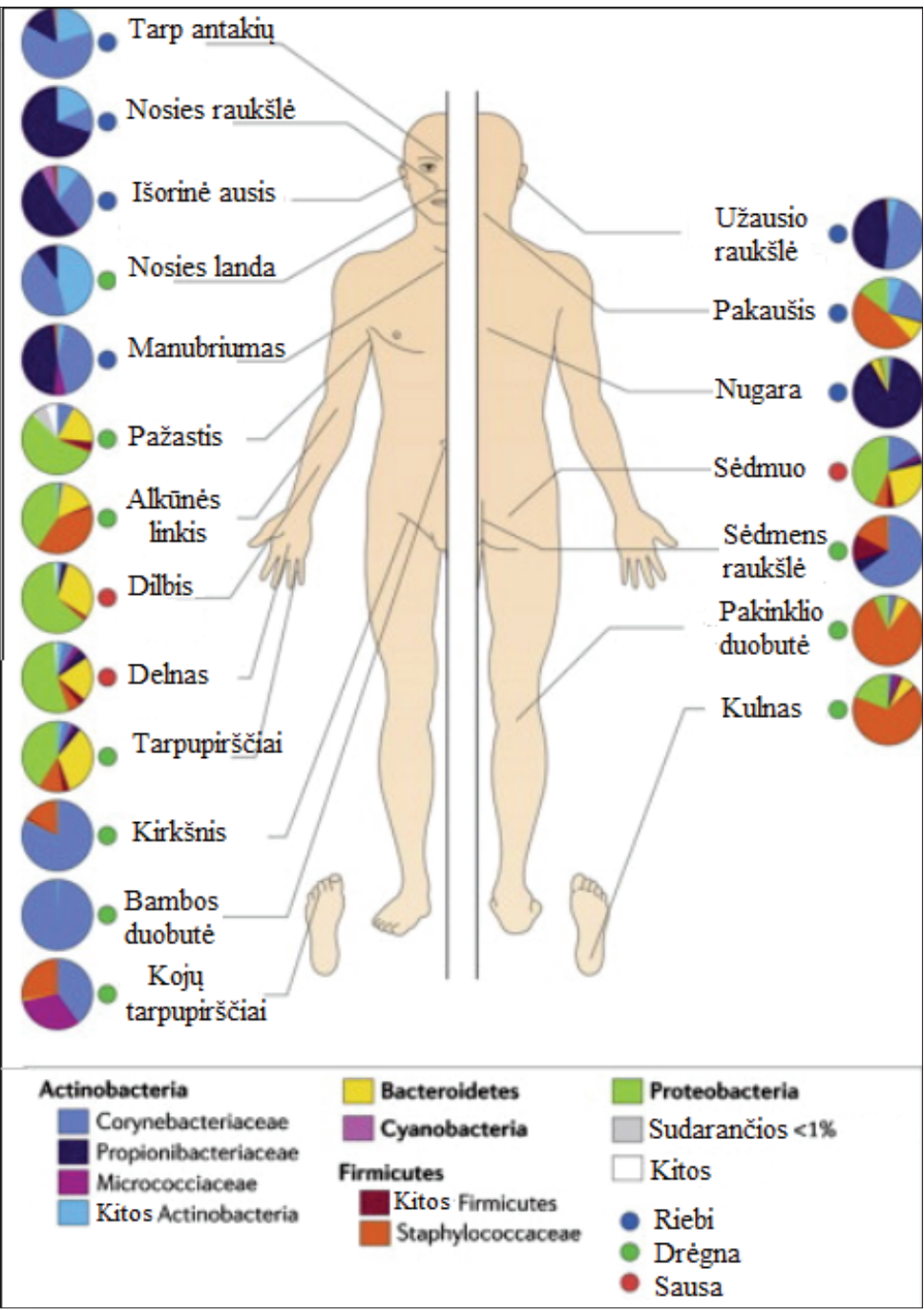

3 pav. Skirtingų žmogaus anatominių vietų mikroorganizmų bendrijų sudètis. Modifikuota pagal [16]

tojami vaistai (ypač antibiotikai ir biocidai). Vaisiaus oda gimdoje yra sterili, tačiau gimdymo metu odą pradeda kolonizuoti Lactobacillus, Prevotella ar Sneathia gentims priskiriami makšties mikroorganizmai. Jie aptinkami ant natūraliai gimusių naujagimių odos iškart po gimimo ir atlieka apsauginę funkciją nuo patogeninių mikroorganizmų. Šios apsaugos negauna kūdikiai, kurie gimsta atliekant cezario pjūvị. Tokių naujagimių odos mikrobiomas panašus ị suaugusiujjų. Ant jų odos aptinkamos Staphylococcus, Corynebacterium ir Propionibacterium gentims priskiriamos bakterijos [30]. Minèti mokslininkai tyrè jaunesnius kaip 2 dienų naujagimius ir nustate specifinius odos mikrobiomo skirtumus, kurie ateityje gali tapti ligos vystymosi priežastimi. JAV mokslininkai sukūrè metodą, kai iš motinos, kuriai prognozuojamas cezario pjūvis, paimami vaginaliniai mikroorganizmai, pašalinami patogenai, išgryninamos pagrindinès dominantès (dažniausiai Lactobacillus bakterijos) ir 
ką tik gimęs kūdikis jomis nuprausiamas. Taip kūdikis gauna tuos mikroorganizmus, kuriuos gautu gimdamas natūraliai.

Kūdikiui augant, turint sąlytị su aplinka, mikroorganizmų įvairovè dideja. Kūdikysteje Firmicutes bakterijos tampa dominuojančios. Mikroorganizmų skaitlingumas ir rūšinė ìvairove keičiasi lytinio brendimo metu, kai testosterono poveikyje išveša riebalinès liaukos ir pagausèja riebalų gamyba. Tokios sąlygos tampa palankia terpe daugintis $C$. acnes, anaerobiniam difteroidui, kuris plačiai aptinkamas ir sveikos odos mikrobiome [31]. C. acnes prisideda prie žemo odos $\mathrm{pH}$ palaikymo, produkuoja riebiąsias rūgštis ir blokuoja patogenų (t.y. Staphylococcus aureus ir Streptococcus pyogenes) kolonizaciją ant odos [15; 32].

Senėjimo laikotarpiu bakterijų ịvairovès pokyčiai siejami su odos savybių pokyčiais. Pažymètina, kad tarpasmeniniai bakterijų îvairovès skirtumai yra didesni, nei pokyčiai laiko atžvilgiu. Sveikų suaugusių žmonių odos mikrobiologiniai tyrimai parode, kad odos mikrobiomas yra santykinai stabilus ilgus mènesius ar metus, ir kad kiekvienas asmuo gali tureti individualizuotą, unikalų odos mikrobiomą - kaip piršto atspaudą [33-34].

Lyčių fiziologiniai skirtumai yra svarbus veiksnys, lemiantis bakterijų įvairovę. Šie skirtumai, greičiausiai, atsiranda dẻl lytinių hormonų veiklos. Pavyzdžiui, androgenai lemia odos storį, bei prakaito ir riebalinių liaukų aktyvumą, nuo kurių priklauso odos biocheminės savybès. Manoma, kad net plaukų buvimas ar nebuvimas gali sukelti alternatyvią mikroaplinką, gebančią palaikyti specifinių mikroorganizmų augimą ir ịvairovę. İdomu tai, kad kai kurie tyrimai rodo rūgštesnị moterų odos $\mathrm{pH}$ [35]. Moterų delnai ir dilbiai kolonizuojami įvairesnių mikroorganizmų rinkinio, nei vyrų. Tyrimų rezultatai rodo, kad abiturientų vyrų ir moterų delnų odos paviršiuje stebimos reikšmingai skirtingos bakterijų bendrijos [36]. D. Hospodsky ir kt. (2014) skirtumų tarp vyrų ir moterų odos bakterijų taksonų nenustate, tačiau pastebėjo ryškius skirtumus tarp daugelio bakterijų grupių santykinio gausumo. Pavyzdžiui, Propionibacterium ir Corynebacterium genčiu bakterijos buvo 37 ir 80 proc. atitinkamai gausesnès ant vyrų odos. Vyrams nustatyta tendencija didèti Staphylococcus gausumui. Priešingai, Enterobacteriales, Moraxellaceae, Lactobacillaceae ir Pseudomonadaceae buvo daugiau kaip 150 proc. tarp moterų. Skirtingų lyčių sẻdmenų, kaktos ir dilbio sričių bakterijų tyrimai parodė stiprią lyties įtaką. Vyrams nustatytas didesnis santykinis gausumas Corynebacterium, Dermacoccus, Streptococcus ir Finegoldia, moterims - Lactobacillus, Propionibacterium, Staphylococcus ir Enhydrobacter. Nepaisant atskiru taksonų santykinio gausumo skirtumų, visoje mikroorganizmų bendrijoje reikšmingų skirtumų tarp lyčių nebuvo nustatyta [37]. Tai rodo, kad individualūs žmonių požymiai yra geriausi kintamumo rodikliai. Tokị lyčiu skirtumą iš dalies galima paaiškinti skirtinga veikla bei elgesio ịpročiais, pvz., tokiais, kaip kosmetikos naudojimas [38].

\section{Išvados}

1. Odos mikrobiomą formuoja įvairių sistematinių grupių atstovai - bakterijos, grybeliai, erkutès ir virusai.

2. Išskirti 4 dominuojantys bakterijų tipai: Actinobacteria (t.y. Corynebacteriaceae, Propionibacteriaceae) (52\%), Firmicutes (t.y. Staphylococcaceae) (24\%), Proteobacteria $(17 \%)$ ir Bacteroidetes (7\%). Daugiau nei 60 proc. bakterijų rūšių priklauso trims gentims: Staphylococcus (Firmicutes), Corynebacterium ir Propionibacterium (Actinobacteria). Odos mikrobiome dažniausiai aptinkami Malassezia genties grybeliai, būdingiausi atstovai: M. limitta, M. globosa ir M. sympodialis. Aptinkamos Demodex genties dvi erkučių rūšys: Demodex folliculorum ir D. brevis. Daugumoje odos vietų didžiają odos viromo dalį sudaro bakteriofagai - DNR virusai: poliomavirusai, papilomos ir raupu.

3. Odos mikrobiomo ịvairovés kokybinius ir kiekybinius skirtumus lemia mikroorganizmų gyvenamosios aplinkos, sąlygų ( $\mathrm{pH}$, temperatūra, drègmè, maisto medžiagos, antimikrobinès molekulès, deguonies koncentracija ir kt.) kaita, mikroorganizmų tarpusavio sąveika, žmogaus amžius, lytis, imuninès sistemos savybès bei individualios elgsenos savybès.

\section{Literatūra}

1. Grice EA, Segre JA. The skin microbiome. Nat. Rev. Microbiol 2011;9:244-53.

https://doi.org/10.1038/nrmicro2537

2. Gallo RL. Human skin is the largest epithelial surface for interaction with microbes. J Invest Dermatol 2017;137:213-1214.

https://doi.org/10.1016/j.jid.2016.11.045

3. Pasparakis M, Haase I, Nestle F. Mechanisms regulating skin immunity and inflammation. Nat Rev Immunol.2014;14:289-301. https://doi.org/10.1038/nri3646

4. Fyhrquist N, Salava A, Auvinen P, et al. Skin Biomes. Curr Allergy Asthma Rep 2016;16:40. https://doi.org/10.1007/s11882-016-0618-5

5. Paller AS, Kong HH, Seed P, Naik S, Scharschmidt TC, Gallo RL, Luger T, Irvine AD. The microbiome in patients with atopic dermatitis. Journal of Allergy and Clinical Immunology 2019; 143(1):26-35.

https://doi.org/10.1016/j.jaci.2018.11.015

6. Balato A, Cacciapuoti S, Di Caprio R, Marasca C, Masarà A, Raimondo A, Fabbrocini G. Human microbiome: composition and role in inflammatory skin diseases. Arch Immunol Ther 
Exp 2019;67(1):1-18.

https://doi.org/10.1007/s00005-018-0528-4

7. Byrd AL, Belkaid Y, Segre JA. The human skin microbiome. Nat Rev Microbiol 2018;16:143-155. https://doi.org/10.1038/nrmicro.2017.157

8. Palm NW, de Zoete MR, Flavell RA. Immune-microbiota interactions in health and disease. Clin Immunol 2015;159:122127. https://doi.org/10.1016/j.clim.2015.05.014

9. Kong HH, Segre JA. Skin microbiome: looking back to move forward. Journal of Investigative Dermatology 2012;132,3(2):933-939.

https://doi.org/10.1038/jid.2011.417

10. Bewick S, Gurarie E, Weissman JL, Beattie J, Davati C, Flint R, Thielen P, Breitwieser F, Karig D, Fagan WF. Trait-based analysis of the human skin microbiome. Microbiome 2019;7:101. https://doi.org/10.1186/s40168-019-0698-2

11. Fitz-Gibbon S, Tomida S, Chiu BH, Nguyen L, Du C, Liu M, Elashoff D, Erfe MC, Loncaric A, Kim J, Modlin RL, Miller JF, Sodergren E, Craft N, Weinstock GM, Li H. Propionibacterium acnes strain populations in the human skin microbiome associated with acne. J Invest Dermatol 2013;133(9):586. https://doi.org/10.1038/jid.2013.21

12. Levac D, Colquhoun H, O'Brien K. Scoping studies: advancing the methodology implementation science 2010;5:69. https://doi.org/10.1186/1748-5908-5-69

13. Picardo M, Ottaviani M, Camera E, Mastrofrancesco A. Sebaceous gland lipids. Dermatoendocrinol 2009;1:68-71. https://doi.org/10.4161/derm.1.2.8472

14. Zhang LJ, Gallo RL. Antimicrobial peptides. Curr Biol 2016;(26)1: R14-R19. https://doi.org/10.1016/j.cub.2015.11.017

15. Dreno B, Martin R, Moyal D, Henley JB, Khammari A, Seite S. Skin microbiome and acne vulgaris: Staphylococcus, a new actor in acne. Exp Derm 2017;26:798-803. https://doi.org/10.1111/exd.13296

16. Grice EA, Kong HH, Conlan S, et al. Topographical and temporal diversity of the human skin microbiome. Science 2009;324:1190-2.

https://doi.org/10.1126/science. 1171700

17. Natsuga K. Epidermal barriers. Cold Spring Harbor Perspect Med 2014;4:1-18. https://doi.org/10.1101/cshperspect.a018218

18. Kong HH, Segre JA. The molecular revolution in cutaneous biology: investigating the skin microbiome. J Invest Dermatol 2017; 137:119-122. https://doi.org/10.1016/j.jid.2016.07.045

19. Akaza N, Akamatsu H, Numata S, Yamada S, Yagami A, Nakata S, Matsunaga K. Microorganisms inhabiting follicular contents of facial acne are not only Propionibacterium but also Malas- sezia spp. J Dermatol 2016;43:906-911.

https://doi.org/10.1111/1346-8138.13245

20. Wang Y, Dai A, Huang S, Kuo S, Shu M, Tapia CP, Yu J, Two A, Zhang H, Gallo RL, et al. Propionic acid and its esterified derivative suppress the growth of methicillin-resistant Staphylococcus aureus USA300. Benef Microbes 2014;5:161-168. https://doi.org/10.3920/BM2013.0031

21. Christensen GJ, Scholz CF, Enghild J, Rohde H, Kilian M, Thurmer A, Brzuszkiewicz E, Lomholt HB, Bruggemann H. Antagonism between Staphylococcus epidermidis and Propionibacterium acnes and its genomic basis. BMC Genom 2016; 17:152. https://doi.org/10.1186/s12864-016-2489-5

22. Oh J, Byrd AL, Deming $\mathrm{C}$ et al. Biogeography and individuality shape function in the human skin metagenome. Nature 2014;514:59-64.

https://doi.org/10.1038/nature13786

23. Findley K, Oh J, Yang J, et al. Topographic diversity of fungal and bacterial communities in human skin. Nature 2013;498:367-370

https://doi.org/10.1038/nature12171

24. $\mathrm{Xu} \mathrm{H}, \mathrm{Li} \mathrm{H}$. Acne, the skin microbiome, and antibiotic treatment. Am J Clin Dermatol 2019;20:335-344.

https://doi.org/10.1007/s40257-018-00417-3

25. Lynn DD, T Umari, CA Dunnick, RP Dellavalle. The epidemiology of acne vulgaris in late adolescence. Health Med Ther 2016;7:13-25.

https://doi.org/10.2147/AHMT.S55832

26. Lacey N, Ní Raghallaigh S, Powell FC. Demodex mites--commensals, parasites or mutualistic organisms? Dermatology 2011;222(2):128-130.

https://doi.org/10.1159/000323009

27. Delwart E. A roadmap to the human virome. PLoS Pathog 2013;9:1003-1046.

https://doi.org/10.1371/journal.ppat.1003146

28. Hannigan GD, Meisel JS, Tyldsley AS, et al. The human skin double - stranded DNA virome: topographical and temporal diversity, genetic enrichment, and dynamic associations with the host microbiome. mBio 2015;6:1578-1615.

https://doi.org/10.1128/mBio.01578-15

29. Prescott SL, Larcombe D, Logan AC, et al. The skin microbiome: impact of modern environments on skin ecology, barrier integrity, and systemic immune programming. World Allergy Organ J 2017;10:29.

https://doi.org/10.1186/s40413-017-0160-5

30. Chu DM, Ma J, Prince AL, Antony KM, Seferovic MD, Aagaard KM. Maturation of the infant microbiome community structure and function across multiple body sites and in relation to mode of delivery. Nat Med 2017; 23:314-326.

https://doi.org/10.1038/nm.4272

31. Jahns AC, Eilers H, Ganceviciene R, Alexeyev OA. Propio- 
nibacterium species and follicular keratinocyte activation in acneic and normal skin. Br J Dermatol 2015;172(4):981-7. https://doi.org/10.1111/bjd.13436

32. Christensen GJ, Bruggemann H. Bacterial skin commensals and their role as host guardians. Benef Microbes 2014;5:201-215. https://doi.org/10.3920/BM2012.0062

33. Oh J, Byrd AL, Park M, NISC Comparative Sequencing Program, Kong HH, Segre JA. Temporal stability of the human skin microbiome. Cell 2016;165(4):854-866. https://doi.org/10.1016/j.cell.2016.04.008

34. Lee YB, EJ Byun, HS Kim. Potential role of the microbiome in acne: a comprehensive review. J Clin Med 2019;8(7):987. https://doi.org/10.3390/jcm8070987

35. SanMiguel A, Grice EA. Interactions between host factors and the skin microbiome. Cell Mol Life Sci 2015;72:1499. https://doi.org/10.1007/s00018-014-1812-Z

36. Ling Z, Liu X, Luo Y, Yuan L, Nelson KE, Wang Y, Xiang C, Li L. Pyrosequencing analysis of the human microbiota of healthy Chinese undergraduates. BMC Genom 2013;14:390. https://doi.org/10.1186/1471-2164-14-390

37. Hospodsky D, Pickering AJ, Julian TR, Miller D, Gorthala S, Boehm AB, Peccia J. Hand bacterial communities vary across two different human populations. Microbiology 2014;160(6):1144-1152.

https://doi.org/10.1099/mic.0.075390-0

38. Tan J, Bhate K. A global perspective on the epidemiology of acne. British Journal of Dermatology 2015;172:3-12.

https://doi.org/10.1111/bjd.13462

\section{SKIN MICROBIOME: DIVERSITY AND IMPORTANCE FOR SKIN HEALTH \\ R. Jankauskienė, G. Šniepienè}

Keywords: skin microbiome, diversity, interactions, skin health. Summary

The skin is our most exposed organ, responsible for providing a barrier to the external environment. The human skin microbiome is the collection of all the microorganisms (including eukaryotes) living in association with the human body: bacteria, fungi, skin mites and viruses. It is estimate that on the human skin inhabit by approximately one million bacteria/ $\mathrm{cm}^{2}$. These microorganisms to vary between individuals and between different sites on the skin. The skin provides many niches in which large populations of microbes are subject to variable ecological pressures including humidity, temperature, $\mathrm{pH}$ and the composition of antimicrobial peptides and lipids. In addition, skin structures such as hair follicles, sebaceous, eccrine and apocrine glands constitute discrete niches that harbor unique microbiota. The recent research on the human microbiome has provided data that suggest that these microbes are generally not harmful to us, they are essential for maintaining health and could be used to treat illnesses. This review focuses on recent evidences about human microbiome composition and functions in interaction with host endogenous and exogenous factors. These new insights can be use into diagnostic, therapeutic and preventive measures in the context of personalized/precision medicine.

Correspondence to: r.jankauskiene@kvk.lt

Gauta 2020-02-20 